Geliş Tarihi:

13.07.2020

Kabul Tarihi:

02.06.2021

Yayımlanma Tarihi:

25.06.2021
Kaynakça Gösterimi: Yildiz, O. (2021). Is there a relationship between the institutional success of universities in webometric ranking system and their popularity on Facebook? A holistic case of Turkish universities. İstanbul Ticaret Üniversitesi Sosyal Bilimler Dergisi, 40(20), 310-330. doi: 10.46928/iticusbe.768930

\title{
IS THERE A RELATIONSHIP BETWEEN THE INSTITUTIONAL SUCCESS OF UNIVERSITIES IN WEBOMETRIC RANKING SYSTEM AND THEIR POPULARITY ON FACEBOOK? A HOLISTIC CASE OF TURKISH UNIVERSITIES
}

Araştırma

Orkun Yildiz (iD) $\mathrm{p}$

Sorumlu Yazar (Correspondence)

Izmir Democracy University

yildiz.orkun@gmail.com

Orkun Yildiz is a faculty member in the Department of Management Information Systems at Izmir Democracy University, Turkey. He teaches and publishes scientific research in the fields of business value chain digital transformation, e/m commerce, enterprise business systems, and human-computer interaction. 


\title{
IS THERE A RELATIONSHIP BETWEEN THE INSTITUTIONAL SUCCESS OF UNIVERSITIES IN WEBOMETRIC RANKING SYSTEM AND THEIR POPULARITY ON FACEBOOK? A HOLISTIC CASE OF TURKISH UNIVERSITIES
}

\author{
Orkun Yildiz \\ yildiz.orkun@gmail.com
}

\begin{abstract}
Purpose: Social media is among the most important digital platforms that bring individuals and institutions together. In the digital age, universities use social media to share news and updates about the institution, research, teaching and social activities. Perhaps, one of the most critical indicators of success in the university account management process in social media might be the number of followers. Hence, this study examined whether there is a relationship between universities' Facebook official account follower counts and universities’ position in the Webometrics university success ranking scale, which is an indicator of universities' institutional success.
\end{abstract}

Method: The present study focused on 161 universities located in Turkey. The official Facebook accounts of these institutions and ranking success position in Webometrics were examined by using two different secondary data sets from 2017.

Findings: The assumed relationships were tested through correlation analyses by using SPSS 20 statistical software. The results showed that there was a significant relationship between universities' follower counts on Facebook pages and Webometrics ranking scores.

Originality: This study would be a pioneering research that can contribute to the literature on the relationship between the success of higher education institutions in Webometric ranking and the popularity of official accounts in a social media channel. Considering the results of this research, it is expected that the top managers of higher education institutions and universities will contribute to institutional value management.

Keywords: Institutional Ranking Success, Social Media Popularity, Universities, Webometrics

JEL Classification: M10, M15, M31 


\section{WEBOMETRİK SIRALAMA SISTEMINDEKİ ÜNIVERSITELERİN KURUMSAL BAŞARILARI ILLE FACEBOOK POPÜLERITELERİ ARASINDA BİR İLISSKİ VAR MIDIR? TÜRK ÜNİVERSITTELERİNİN BÜTÜNSEL ÖRNEĞİ}

\section{ÖZET}

Amaç: Sosyal medya bireyleri ve kurumları bir araya getiren en önemli dijital platformlar arasındadır. Dijital çağda, üniversiteler sosyal medyayı haberler ve kurumları, araştırmaları, öğretim ve sosyal faaliyetleri hakkında güncel bilgileri paylaşmak için kullanmaktadırlar. Sosyal medyada başarılı bir üniversite hesabı yönetim sürecinin belki de en önemli göstergelerinden bir tanesi takipçi sayısıdır. Bu nedenle, bu çalışmada üniversitelerin kurumsal başarılarının bir göstergesi olan üniversitelerin Facebook resmi hesap takip sayıları ile üniversitelerin Webometrics üniversite başarı sıralaması ölçeği arasındaki ilişki arasında bir ilişki olup olmadığını incelenmiştir.

Yöntem: Çalı̧̧mada Türkiye'de bulunan 161 üniversiteye odaklanılmıştır. Bu kurumların resmi Facebook hesaplarının takipçileri ile Webometrics'de yer aldıkları başarı sıraları 2017 yılında iki farklı ikincil veri seti kullanılarak gerçekleştirilmiştir.

Bulgular: Varsayılan ilişkiler korelasyon analizleri ve SPSS 20 istatistik yazılımı kullanılarak test edilmiştir. Sonuçlar, üniversitelerin Facebook sayfalarındaki takipçi sayıları ile Webometrics sıralama puanları arasında anlamlı bir ilişki olduğunu göstermiş̧ir.

Özgünlük: Bu çalışma, elde ettiği bulgularla yükseköğretim kurumlarının Webometrik sıralamasındaki başarısı ile bir sosyal medya kanalındaki resmi hesap popülerlikleri arasındaki ilişkiye yönelik literatürde katkı sağlayabilecek öncü bir araştırma olacaktır. Bu araştırma sonuçları dikkate alındığında yükseköğretim kurumlarının üst yöneticileri ve üniversitelerin kurumsal değer yönetimi için katkı sağlayacağı beklenmektedir.

Anahtar Kelimeler: Kurumsal Başarı Sıralaması, Sosyal Medya Popülerliği, Üniversiteler, Webometriks

JEL Sinıflandırması: M10, M15, M31 


\section{INTRODUCTION}

Information exchange grows incrementally due to technological developments and globalization all over the world. Therefore, the impact and importance of information management are better understood these days than ever before. A significant number of technological developments have taken place in many sectors. One of these sectors is the communication sector. This sector is crucial to understanding the functioning mechanisms for private and public sectors because communication is vital to business processes. Communication technologies, public institutions, and private sector memberships have used communication channels to conduct appropriate political, commercial, public relational, and social responsibility activities to meet their goals.

Many different communication channels have been developed to help these aforementioned activities, but some of their impact on these activities are stronger than others. Social media tools such as Facebook, Twitter, Instagram, and Blogs are some of these channels. Social media tools gain a significant role among the new communication channels, and PR messages can reach millions of people with less effort than before, thanks to social media tools in recent years. It is possible to say that social media tools are unique media channels to make public relations activities for the private and public sectors because these tools provide the opportunity to announce their business and social activities. These announcements can be made with less cost, fewer persons, and shorter time than other communication channels. It is seen that social media tools may be of great importance to render communication activities not only for the private but also for the public sector to do public relations activities. After reviewing the literature, it seems that no study has investigated public institutions' public relations managed through social media tools. This gap is the most crucial driver for conducting the present study. This study aims to understand the link between universities' Facebook popularity and their position in the Webometrics ranking system.

\section{LITERATURE REVIEW AND HYPOTHESES}

\section{Public Relations and Higher Education Institutions}

Public relations (PR) are a fascinating research area for various academic disciplines such as management, sociology, journalism, and others. This research area has been developing for over 40 years as a relatively young discipline with a theoretical and research basis (Childers, 1989). PR practitioners managed narrow traditional communicational channels to promote organizations (Lahav, 2014). However, this method must be changed by the enormous impact of the internet age. One-the way traditional activities have evolved into two-way communication between organizations and key populations such as governments, news media, clients, employees, investors, and contributors (Avidar, 2011; Esrock \& Leichty, 1998). The population that has access to the internet has incredibly grown in the last decade. 
These days more than one-third of the world's population have an internet connection (Internetworldstats, 2015). Dialogue and dissent/protest PR concepts have gained increasing significance. Public relations affect new sources, and this fact can be seen in countries that have close economic and/or gaps on freedom of speech, such as China, North Korea, the Middle East countries (Avidar, 2011; Chen, Chen \& Chen, 2012; Hou et al., 2013; Lahav, 2014). On the other hand, many studies have been conducted to understand internet use and its impact on public relations (PR) activities. Most of these studies focus on website communication as a tool of public relation activities on the internet (Adi, 2015; Basil \& Erlandson, 2008; Curtis, Edward, Fraser, Gudelsky, Holmquist, Thornton \& Sweetser, 2010; Esrock \& Leichty, 2000; Lovejoy, Waters \& Saxton, 2012; McAllisterSpooner, 2009; Sommerfeldt, Kent \& Taylor, 2012). These studies have revealed that many groups' success in public relations (PR) activities have been achieved through website communication. Some of these studies have focused on understanding these activities and providing solutions for public activities between corporations and target groups (Adi, 2015; Adi \& Miah, 2011; Adi \& Moloney, 2012; Callison, 2003), while others have examined how the response of institutions should be to achieve success activism in public relation (Adi, 2015; Hallahan, 2001; Jun, 2011; Lee, Park, Sun, Lee, \& Cameron., 2010; Van Leuven, Deprez \& Raeymaeckers, 2013; Zietsma \&Winn, 2007).

\section{Social Media and Higher Education Institutions}

Social media tools are among the most used channels for consumers, companies, and institutions to communicate, advertise, and manage public relations activities. If this popularity continues, social media will be a leader channel for many communication activities. Social media channels reshape all rules in traditional public relations methods (DiStaso, McCorkindale \& Wright, 2011) and are likely to be the main channels of PR practices. However, a few studies have focused on these tools in the field of public relations, and also, they have claimed that social media tools are essential for many organizations. Some researchers argue that social media provides benefits for non-profit and profit institutions that cannot be used effectively (Allagui \& Breslow 2016; Valentini, 2015), while others claim the opposite (DiStaso et al., 2011; Dougall, 2006). Nevertheless, some studies aim to determine the quality requirements for achieving success PR works by non-profit institutions (Kent, 2010; Sanderson, Barnes, Williamson \& Kian, 2016).

Social media channels will be key players to achieve well-organized public relations' (PR) works for organizations in the future, thanks to increasing communication relations. Social media tools enhance communication between organizations (Lee, Xiong \& Hu, 2012; Myers, 2015; Shin, Carithers, Lee, Graham \& Hendricks, 2013; Valentini \& Kruckeberg, 2012). PR professionals use social media tools to speak directly to their followers and stakeholders without any interruptions nowadays (Verhoeven, Tench, Zerfass, Moreno \& Verčič,, 2012), and for instance, the campaigns of social media PR have potential for success during election campaigns (Kilic \& Ataberk, 2012; Allagui \& Breslow, 2016; De Busy \& Wolf, 2009; Eyrich, Padman \& Sweetser, 2008; Frame \& Brachotte, 2015; Momoc, 2013). 
Campaign tactics of social media and traditional media channels such as television, radio, and newspapers are different, which has been investigated in many articles. Human rights advocacy groups emphasize the link between free speech and human rights (Adi \& Miah, 2011). Social media tools provide facilities for freedom speeches on public relations activities. The symmetry of communication is powerful effectiveness, and it has been an important fact to understand the evolution of academic studies on public relations in the last decade (Chen \& Chan, 2014; Chen et al., 2012).

Many case studies also have focused on the effects of public relation activities and/or social media tools on communication for social happenings and public and voluntary sectors in the PR literature (Adi \& Moloney, 2012; Lee et al., 2012; Lovejoy, Waters, \& Saxton, 2012; Moore \& Carlson, 2013; Paek, Hove, Jung \& Cole, 2013). In addition to this, social media researchers have investigated communication strategies and protesters' actions and PR perspectives of online media communication tools (Adi, 2015; Sommerfeldt et al., 2012; Van Der Meer , Verhoeven, Beentjes \& Vliegenthart, 2014). Also, studies have discussed social media tools’ impact on organizations.

Since social media tools affect society, evaluating social media PR works in line with ethic rules, and presenting its power on access and effect on millions is another subject in the literature (Rubin, 2011; Toledano \& Avidar, 2016; Toledano \& Wolland, 2011). Ethical rules for social media tools are not taken into consideration. Also, ethical rules may not be controlled as much as required by supervisor institutions so that governments may support the number of volunteer public organizations to increase them. Therefore, the number of social media tools users are increasing by applying ethical rules on social media. Organization's adoption of social media tools (SMT) to achieve PR works through social media channels and factors that impact organizations' adoption of social media tools (SMT) is a study field for a few researchers (Triantafillidou \& Yannas, 2014; Valentini \& Kruckeberg, 2012; Waters, Burnett, Lamm \& Lucas, 2009; Willis, 2015; Xifra \& Huertas, 2008). These studies have aimed to understand the essential factors that increase social media tools usage and reveal how organizations can be successful while adopting social media tools to carry out public relations activities. Therefore, it is understood that PR practitioners heavily use social media channels, NGOs, and corporations to achieve their goals.

Higher education institutions are among the bodies that use social media for PR activities. After conducting a literature review for this study, it was found out that few studies existed on the higher education institutions and their social media and PR management strategies in the literature. There are many negative and positive findings of the relationship between social media and higher education public relations in scientific studies. For instance, the use of social media network channels could negatively affect the image of higher education institutions (Anisimova, Vasylenko, \& Fedushko, 2019). Because higher education institutions need to involve with two-way communication, dialogue and engagement on social media, but some universities do not engage with such activities in an 
efficient way. These higher education institutions have used social media as only broadcasting channels or advertising platforms (Constantinides \& Stagno, 2012). To illustrate, it has been found that social media channel of universities have been the last visited source of information among candidate students in the Netherlands since most of the higher education institutions do not have official social media accounts or have good content management (Constantinides \& Stagno, 2012).

On the other hand, there is an ample evidence for institutional branding activities that focus on the use of social media in higher education. Furthermore, these activities impact the development of the relationship between an institution and the public and gain students' brand loyalty towards the institution (Eger, Egerova, \& Kryston, 2019). Moreover, universities' promotional campaigns can be done transparently on social media and this situation could increase institutional trust thanks to communication activities with users on social media channels (Maresova, Hruska, \& Kuca, 2020). Besides, positive comments may positively affect candidate students' university selections, while negative comments may cause results vice versa (Desai \& Han, 2019). Thus, it can be concluded that universities' activities on social media may have a direct impact on today's generation (Desai \& Han, 2019).Altogether, it can be said that updated and creative content production, professional channel management, and top managers support to institutional social media channel are essential to managing the institutional image of universities on social media channels.

In other words, higher education institutions should reconsider how they use social media tools and explore ways to influence positive change in education communities and society at large by using these tools more effectively (Kimmons, Veletsianos, \& Woodward, 2017). If these issues are considered carefully, it would become possible for higher education institutions to use social media channels effectively.

In this study, we focus on the higher education institutions in Turkey. After the literature was comprehensively examined, we determined a few studies with a similar target population, the higher education institutions in Turkey and their social media presence. One of these works was carried out by Futurearts, a research company. This company collected data about official social media use from 106 public and 55 foundation higher education institutions from Turkey in 2011. It can be said that this study only focused on the existence of universities' official social media sites, which are Facebook, Twitter, Friendfeed, Linkedin, Formspring, Foursquare, Youtube, Dailymotion, Vimeo, Flickr, Blogger and Tumblr social media networks. According to this study results, $21 \%$ of public and $73 \%$ of foundation universities have one official social media channel (Futurearts, 2011). On the other hand, another scientific research has been conducted on how university students follow their universities' social media accounts (Gümüş, Türkel \& Gözde, 2015). According to this study, 75 public and 61 foundation universities had an official social media accounted in 2014. Also, Seçkiner \& Tahtalioglu (2017) have contributed to another scientific research consisting of higher education institutions and their usage of social media channels in the literature. According to this study results 
that $96 \%$ of public universities (108 to 113) had a Facebook or Twitter official account. Thereby, after doing a comparative evaluation of public universities' social media presence in Turkey from 2014 to 2017, it is understood that there is a highly increasing ratio of official social media channel presence (from 80\% to 96). Furthermore, as understood from this comparable statistical result, the number of social media followers indicate continuously varying, dynamic, and numerical data that are based on time. Hence, we determined a specific time point suitable for our research aims.

\section{METHODOLOGY}

\section{Research Questions}

This study investigates the relationship between the popularity of universities' official Facebook accounts and their ranked position success in WEBO ranking in 2017. Also, it focuses on the state and foundation universities having an official Facebook account and the position in Webometrics' ranking in the last quarter of 2017.

The relation between universities' follower counts on official Facebook pages, and ranking success has not been investigated in the literature. Hence, this study aims to complete this gap in the literature. Specifically, the study's research question is, "Is there a relationship between the number of followers on universities' official Facebook account and their ranked position achievement in Webometrics?”

To determine whether there is a relationship between the dependent variable (the position in Webometrics ranking) and the independent variable (The number of followers on official Facebook account). On the other hand, research and sampling design have been conducted following the research question by considering the time and financial constraints. The hypothesis of this study are presented below:

$\mathrm{H}_{\mathrm{o}}=$ There is no relationship between official Facebook account popularity and Webometric ranking achievement for Turkey's higher education institutions.

$\mathrm{H}_{1}=$ There is a relationship between official Facebook account popularity and Webometric ranking achievement for Turkey's higher education institutions.

Detailed information about the research and sampling design is presented below.

Data Collection and Analysis Methods

In this study, secondary data sets were used from two different sources. Secondary data collection is such a valuable strategy to conduct different research aim by using the exact data for researchers to provide cost, time and effort savings (Hox \& Boeije, 2005). Of course, some critical factors should be considered regarding the original research from which the data was taken. The factors in question are the purpose of the research, the sampling structure, the limitations of the study, the time it was conducted, and the research content (Doolan \& Froelicher, 2009; Magee, Lee, Giuliano \& Munro, 
2006). Hence, we used the data provided by Seçkiner and Tahtalioglu (2017) on Turkish universities' follower counts on official Facebook pages (dated 06.07.2017).

On the other hand, secondary data set from the Webometric rankings of universities in Turkey is another vital resource for this study aim. According to the official definition of Webometric, "Since 2004, the Ranking Web (or Webometrics Ranking) has been published twice a year (data is collected in the first weeks of January and July to be available to the public at the end of every two months) and covers more than 31,000 Higher Education Institutions worldwide. The purpose of the ranking is to motivate both institutions and academics to have a web presence that accurately reflects their activities” (Webometrics, 2017).

Webometrics is designed to show the individual performance of higher education institutions. Table 1 below details its current methodology:

Table 1. Current Method of Webometrics Ranking of World Universities

\begin{tabular}{|c|c|c|c|c|}
\hline Indicators & Meaning & Methodology & Source & Weight \\
\hline Presence & " Public knowledge shared & " Discontinued & & \\
\hline Visibility & Web contents Impact & $\begin{array}{l}\text { Number of external } \\
\text { networks (subnets) linking } \\
\text { to the institution's webpages } \\
\text { (normalized and then the } \\
\text { maximum value is chosen) }\end{array}$ & Ahrefs Majestic & $50 \%$ \\
\hline $\begin{array}{l}\text { Transparency } \\
\text { (or Openness) }\end{array}$ & Top cited researchers & $\begin{array}{l}\text { Number of citations from } \\
\text { Top } 210 \text { authors (excl. top } \\
20 \text { outliers) See Transparent } \\
\text { Ranking for additional info }\end{array}$ & $\begin{array}{c}\text { Google Scholar } \\
\text { Profiles }\end{array}$ & $10 \%$ \\
\hline $\begin{array}{l}\text { Excellence } \\
\text { (or Scholarly) }\end{array}$ & Top cited papers & $\begin{array}{l}\text { Number of papers amongst } \\
\text { the top } 10 \% \text { most cited in } \\
\text { each one of all } 27 \\
\text { disciplines of the whole } \\
\text { database (Data for the five } \\
\text { years: 2015-2019) }\end{array}$ & Scimago & $40 \%$ \\
\hline
\end{tabular}

Sources: Webometrics, 2021a

Stewart and Kamins (1993) claim that evaluation follows steps such as research appropriately and relevance, quality of the preliminary study, and the resulting data set matching data sets to research. We have examined the data set by taking into account the aforementioned evaluation suggestions, respectively.

Firstly, the Webometrics ranking of the world universities is suitable for our research aim because it has a comprehensive university ranking system, and it does not just include the ranking web of universities. On the contrary, it has all webometric and bibliometric research missions. This ranking system is the most significant academic ranking of the higher education system with independent, objective, free, open scientific exercise inclusive of each six month periods (Webometrics, 2021b). 
Secondly, the primary purpose on which the ranking methodology of higher education institutions is based, Web indicators, are accepted as proxies in the accurate, comprehensive, and in-depth evaluation of the university's global performance, taking into account their activities and outputs and their relevance and effects.

Thirdly, it can be said that the webometric ranking makes a difference with the top-quality higher education institutions around the world and the coverage of the ranking indicators. In other words, webometrics is a ranking system covering all universities in the world. Besides, higher education institutions whose standards are on a world scale are generally not small or highly specialized institutions, and finally, webometrics continually researches to improve rankings, change or refine indicators and weighting model to provide a better classification (Webometrics, 2021c).

After carrying out these evaluation stages, it was determined that the webometric ranking data set of 2017 is suitable for our research. After researching these universities, we detected that 96 public, and 51 private universities are ranked in the Webometric in 2017 with the official Facebook account. Hence, we have analyzed the relationship between the number of official Facebook account followers and their Webometrics ranking position.

The official accounts of the universities were visited, and the latest figures were determined and used. As seen below, Table 2. shows detailed information about the WEBO ranking positions and Facebook follower numbers of universities in Turkey. The top 10 universities that have the highest positions of ranking in Webometric are Middle East Technical University (473), Istanbul Technical University (604), Boğaziçi University (626), Hacettepe University (641), Istanbul University (738), Ankara University (752), Iskenderun Technical University (757), Mardin Artuklu University (884), Gazi University (941), and Marmara University (1041). Therefore, it could be said that public universities have better positions than foundation universities in Turkey in the top 10 list of Weboranking. Consequently, these universities are ranked based on the follower numbers on the official Facebook account as the following: Eskişehir Anadolu University (194.103), Uskudar University (128.186), Istanbul Commerce University (126.625), Istanbul University (120.186), Middle East Technical University (119.625), At1lım University (116.502), Adnan Menderes University (110.185), Bahçeşehir University (107.692), Karadeniz Technical University (101.718), Ordu University (95.617). Therefore, it may be said that some of the foundation universities have a good position in the top 10 in the number of followers on the official account. 
Table 2. The Ranking Positions and the Number of Social Media Followers of Universities in Turkey in 2017

\begin{tabular}{|c|c|c|c|c|c|}
\hline The High. Education Institutions & World Ranking & $\mathrm{N}$ of Followers & The High. Ed. Institutions & World Ranking & $\mathrm{N}$ of Followers \\
\hline Abant Izzet Baysal University & 2153 & 7.161 & Beykoz University & 11429 & 11.026 \\
\hline Abdullah Gül University Kayseri & 3071 & 17.324 & Bezm-i Alem University & 3230 & 1.643 \\
\hline Acıbadem Mehmet Ali Aydınlar University & 3167 & 16.662 & Bilecik Şeyh Edebali University & 5928 & 1.939 \\
\hline Adana Science and Technology University & 3961 & 2.887 & Bingöl University & 2770 & 2.879 \\
\hline Adiyaman University & 2223 & 3.541 & Biruni University & 3920 & 37.039 \\
\hline Adnan Menderes University & 2071 & 110.185 & Bitlis Eren University & 4862 & 2.004 \\
\hline Afyon Kocatepe University & 2169 & 3.422 & Boğaziçi University & 626 & 14.323 \\
\hline Ahi Evran University & 2951 & 1.383 & Bozok University & 2791 & 12.786 \\
\hline Akdeniz University & 1409 & 12.096 & Bursa Teknik University & 3283 & 1.038 \\
\hline Alanya Alaaddin Keykubat University & 12507 & 3.562 & Cappadocia University & 7832 & 26.901 \\
\hline Alanya Hamdullah Emin Pasa University & 15371 & 4.562 & Cumhuriyet University & 1953 & 8.032 \\
\hline Amasya University & 4693 & 7.319 & Çağ University & 3066 & 13.303 \\
\hline Ankara Sosyal Bilimler University & 7846 & 1.934 & Çankiri Karatekin University & 3006 & 8.025 \\
\hline Ankara University & 752 & 68.719 & Çankaya University & 1763 & 5.906 \\
\hline Ankara Yıldırım Beyazıt University & 3743 & 13.692 & Çanakkale On Sekiz Mart University & 1750 & 11.050 \\
\hline Antalya Akev University & 17784 & 3.076 & Çukurova University & 1927 & 17.197 \\
\hline Artvin Çoruh University & 3844 & 8.038 & Dicle University & 2150 & 30.318 \\
\hline Atatürk University & 1091 & 104.249 & Doğuş University & 2104 & 24.496 \\
\hline Atilim University & 2089 & 116.502 & Dokuz Eylül University & 1033 & 46.803 \\
\hline Avrasya University & 11651 & 2.630 & Dumlupinar University & 2550 & 58.607 \\
\hline Bahçeşehir University & 1735 & 107.692 & Düzce University & 3250 & 26.583 \\
\hline Balikesir University & 2183 & 41.026 & Ege University & 1430 & 30.777 \\
\hline Bandirma University & 7221 & 5.055 & Erciyes University & 1863 & 23.915 \\
\hline Bartin University & 3185 & 17.554 & Erzincan Binali Yıldırım University & 3916 & 2.285 \\
\hline Başkent University & 1812 & 14.477 & Erzurum Teknik University & 3826 & 3.983 \\
\hline Batman University & 3661 & 155 & Eskişehir Anatolia University & 1719 & 194.103 \\
\hline Bayburt University & 3724 & 3.549 & Eskişehir Osmangazi University & 1485 & 14.837 \\
\hline Beykent University & 2752 & 78.571 & Firat University & 1600 & 10.887 \\
\hline Gumushane University & 3216 & 15.583 & Hacettepe University & 641 & 80.033 \\
\hline Hakkâri University & 9789 & 2.425 & Izmir Economy University & 2354 & 58.965 \\
\hline Haliç University & 5955 & 10.869 & Izmir Kâtip Celebi University & 3776 & 10.718 \\
\hline Harran University & 1880 & 12.268 & Izmir Institute of Technology & 1437 & 8.485 \\
\hline Hasan Kalyoncu University & 3339 & 33.709 & Kadir Has University & 2580 & 101.718 \\
\hline Health Sciences University Istanbul & 4003 & 8.705 & Kah. Sutcu Imam University & 2437 & 45.162 \\
\hline
\end{tabular}


Table 2. The Ranking Positions and the Number of Social Media Followers of Universities in Turkey in 2017 (Cont.1)

\begin{tabular}{|c|c|c|c|c|c|}
\hline The High. Ed. Institutions & World Ranking & N of Followers & The High. Ed. Institutions & World Ranking & N of Followers \\
\hline Hitit University & 2737 & 6.471 & Karabük University & 2405 & 10.660 \\
\hline Iğdır University & 3726 & 781 & Karadeniz Technical University & 1371 & 5.845 \\
\hline Işık University & 3099 & 24.451 & Karamanoğlu Mehmetbey University & 3181 & 1.921 \\
\hline İbn Haldun University & 6358 & 4.378 & Kars Kafkas University & 1988 & 10.151 \\
\hline İhsan Doğramacı Bilkent University & 757 & 69.452 & Kirikkale University & 1981 & 15.960 \\
\hline İnönü University & 1960 & 6.073 & Kirklareli University & 4003 & 2.806 \\
\hline Iskenderun Technical University & 3901 & 13.648 & Kilis 7 Aralık University & 6767 & 12.004 \\
\hline Istanbul 29 Mayıs University & 11916 & 7.919 & Kocaeli University & 1770 & 4.823 \\
\hline Istanbul Arel University & 3343 & 70.538 & Koç University & 884 & 87.625 \\
\hline Istanbul Aydin University & 1631 & 126.625 & KTO Karatay University & 3547 & 31.035 \\
\hline İstanbul Ayvansaray University & 15415 & 9.931 & Maltepe University & 3486 & 18.384 \\
\hline Istanbul Bilgi University & 1416 & 200.656 & Manisa Celal Bayar University & 3470 & 35.379 \\
\hline Istanbul Commerce University & 3833 & 50.253 & Mardin Artuklu University & 6600 & 2.971 \\
\hline Istanbul Esenyurt University & 13829 & 25.908 & Marmara University & 1041 & 89.891 \\
\hline Istanbul Gedik University & 6925 & 22.561 & Mehmet Akif Ersoy University & 3177 & 10.827 \\
\hline İstanbul Kent University & 16705 & 185 & Mersin University & 3616 & 9.443 \\
\hline Istanbul Kültür University & 3494 & 57.085 & Middle East Technical University & 473 & 119.625 \\
\hline İstanbul Medeniyet University & 2580 & 8.706 & Mimar Sinan Fine Arts University & 2365 & 5.142 \\
\hline Istanbul Medipol University & 2430 & 85.745 & Muğla Sitkı Koçman University & 2116 & 40.998 \\
\hline İstanbul MEF University & 4610 & 13.493 & Munzur University & 9075 & 3.187 \\
\hline Istanbul Sabahattin Zaim University & 3872 & 13.511 & Mustafa Kemal University & 2513 & 7.285 \\
\hline Istanbul Şehir University & 5392 & 64.413 & Muş Alparslan University & 3920 & 4.764 \\
\hline Istanbul Technical University & 604 & 78.696 & Namik Kemal University & 2424 & 8.777 \\
\hline Istanbul University & 738 & 120.186 & Necmettin Erbakan University & 2463 & 12.089 \\
\hline Istanbul Yeni Yüzyıll University & 7901 & 13.772 & Nevşehir Haci Bekt. Veli University & 3143 & 10.876 \\
\hline Istinye University & 7525 & 10115 & Niğde Ömer Halisdemir University & 2662 & 28.162 \\
\hline
\end{tabular}


Table 2. The Ranking Positions and the Number of Social Media Followers of Universities in Turkey in 2017 (Cont.2)

\begin{tabular}{|c|c|c|c|c|c|}
\hline The High. Ed. Institutions & World Ranking & $\mathrm{N}$ of Followers & The High. Ed. Institutions & World Ranking & $\mathrm{N}$ of Followers \\
\hline Özyeğin University & 1700 & 59.456 & Turkish-German University & 7682 & 172 \\
\hline Pamukkale University & 1310 & 70.359 & Ufuk University & 4480 & 4.040 \\
\hline Piri Reis University & 3274 & 8.641 & Uludağ University & 1317 & 1.846 \\
\hline Recep Tayyip Erdoğan University & 2842 & 3.905 & Uşak University & 3110 & 1.793 \\
\hline Sabanci University & 1045 & 64.902 & Uskudar University & 3480 & 128.186 \\
\hline Sakarya University & 1409 & 44.219 & Yalova University & 3675 & 9.440 \\
\hline Sanko University & 14299 & 3.048 & Yaşar University & 2477 & 64.422 \\
\hline Selçuk University & 1381 & 83.793 & Yeditepe University & 1841 & 40.942 \\
\hline Siirt University & 3644 & 8.201 & Yildiz Technical University & 1097 & 60.722 \\
\hline Sinop University & 2899 & 13.141 & Turkish-German University & 7682 & 172 \\
\hline Suleyman Demirel University & 1593 & 21.902 & Ufuk University & 4480 & 4.040 \\
\hline Şırnak University & 5015 & 8.127 & Uludağ University & 1317 & 1.846 \\
\hline TED University & 2762 & 18.139 & Uşak University & 3110 & 1.793 \\
\hline TOBB Economy and Technology University & 1512 & 33.837 & Uskudar University & 3480 & 128.186 \\
\hline Toros University & 8568 & 7.249 & Yüksek Ihtisas University & 16788 & 327 \\
\hline Trakya University & 2205 & 11.930 & Yüzüncü Yil University & 1826 & 19.311 \\
\hline Turkish Aeronautical Association University & 11281 & 38.354 & Zonguldak Bülent Ecevit Univ. & 2372 & 23.771 \\
\hline
\end{tabular}

Sources: Seçkiner \& Tahtalioğlu, 2017, pp. 2412-2415 


\section{DATA ANALYSIS}

Firstly, descriptive statistics were computed in order to obtain detailed information about the data. The values obtained from these tests are given in Table 3. The number of official Facebook account followers ranged from $155(\mathrm{~min})$ to 200656 (max) for 161 higher education institutions. Moreover, Webometrics rankings varied between 473 and 17784 .

Table 3. Descriptive Statistics for Universities in Turkey

\begin{tabular}{llllll}
\hline \multirow{2}{*}{ Facebook-Followers } & Mean & Std. Dev. & Median & Min. & Max. \\
& 28970.14 & 36673.57 & 28970,14 & 155 & 200656 \\
\hline \multirow{2}{*}{ Webometrics Ranking } & Mean & Std. Dev. & Median & Min. & Max. \\
& \multirow{2}{*}{3976.37} & 3520,15 & 2951 & 473 & 17784 \\
\hline
\end{tabular}

Secondly, a statistical correlation test was applied in order to understand the relationship between official Facebook account popularity and Webometric ranking achievement for 161 higher education institutions in Turkey, as seen in Table 4.

Table 4. Correlation Test Results

\begin{tabular}{l|llll}
\hline \multirow{4}{*}{ Spearman's rho } & Correlation Coefficient & 1.000 & $.487^{* *}$ \\
\cline { 3 - 5 } & Webometrics Ranking & Sig. (2-tailed) & - & .000 \\
& & $\mathrm{~N}$ & 161 & 161 \\
\cline { 2 - 6 } & \multirow{3}{*}{ Facebook Follows } & Correlation Coefficient & 1.000 & $.487^{* *}$ \\
& & Sig. (2-tailed) & - & .000 \\
& $\mathrm{~N}$ & 161 & 161 \\
\hline
\end{tabular}

**Correlation is found to be significant at $p<.001$.

Before correlation test analysis was conducted, necessary arrangements were made in the data so that the university with the highest success ranking in Webometrics would have the highest score by weighing the ranking success of the universities. Since the data were not normally distributed, a Spearman correlational test was applied to the data. The correlational analysis revealed a significant positive correlation between Webometrics ranking and Facebook follower counts $(r=.487, p<.001)$ This result indicates that there exists a positive relationship between "Webometrics Ranking" and "Facebook-Follower counts."

As a result, according to Spearman's rho and significance values, the hypothesis Ho (There is no relationship between official Facebook account popularity and Webometric ranking achievement for higher education institutions in Turkey.) is not accepted at a significance level of .01 (2-tailed). Therefore, it can be said that the $\mathrm{H}_{1}$ hypothesis $\left(\mathrm{H}_{1}=\right.$ There is a relationship between official Facebook account popularity and Webometric ranking achievement for higher education institutions in Turkey.) is accepted at .001 significance levels according to statistical analysis results in this study. 


\section{RESULTS AND DISCUSSION}

There are many different institutions that focus on doing the ranking of international higher education, and their reports are highly taking care of higher education institutions and their partners as an indicator of institutional achievement. Therefore, the high governance of the higher education institutions implication different strategies for being a better position in these ranking for their institutions. Publicity and brand awareness could be one of these unique strategies. For this reason, it is seen that institutional public relations activities are given more importance day by day by higher education institution administrators.

Social media tools are going to be pioneer channels to conduct public relations (PR) practices. Such applications can be seen in many different sectors such as media, politics, business, advertisement, and even the sports sector use social media tools for doing PR activities. At this point, it is essential to understand that they are relevant to social media tools for doing public relations activities by higher education institutions. In other words, public relations (PR) literature may be enlarged by conducting academic studies on social media tools.

This study is critical because it contributes to the PR literature on universities' PR practices. Universities are priority institutions to have a million members, such as students, instructors, and external followers from different points in society. These institutions are one of society's building blocks. However, the PR literature has some gaps related to universities' PR works. This study's contributions should be discussed concerning the progress made in knowledge about the relationship between the successes in Webometrics ranked achievement and the number of followers on universities' official Facebook sites in Turkey. The results obtained from the Spearman correlation analysis indicate that there exists a positive relationship between Webometrics ranked achievement position, and Facebook follower counts for the higher education institutions in Turkey. Of course, it cannot be said that the official Facebook account popularity has a direct effect on the success ranking position in the Webometrics, but there is a positive relation. Put differently, it seems that social media presence and activities of higher education institutions are valuable. Hence, it can be claimed that higher education institutions should try to meet the requirements for gaining popularity on social media channels. Furthermore, universities' social media channels should be managed through effective and informed corporate governance plans that are formulated by decision-makers and top managers in higher education institutions.

\section{SUGGESTIONS}

Universities should make a master plan for PR practices on their official pages and social media channels. This plan should have a structure that includes the social media programs of the universities. Then, the university's services and activities should be planned to cover all steps to meet users' demands on social media. Moreover, rectories in universities should encourage people of interest who are students, administrative staff, and academicians to be active on social media tools. During this period, technical personnel can aid these parties to effectively use social media. The members of the universities' institutional management hierarchy need to support the use of social media tools. Studies on product deployment across 
the enterprise, enhancing staff qualities, search for cooperation, and innovation should all be encouraged in universities. It should not be forgotten that a good database is the most significant advantage of the social media process. This study addresses the relationship between Turkish Universities' success in the Webometrics ranking and their public relations practices by social media channels. Future research may sample with universities that have been on the list of Webometrics rankings from different countries as well. Also, studies may have both different variables and ranking systems to understand how the effect of PR practices by social media tools might be better positioned in international ranking systems. 


\section{REFERENCES}

Adi, A. (2015). Occupy PR: An analysis of online media communications of occupy Wall Street and occupy London. Public Relations Review, 41(4), 508-514. doi:10.1016/j.pubrev.2015.06.001.

Adi, A., Miah, A. (2011). Open source protest: Human rights, online activism and the Beijing 2008 Olympic Games. In Lester, L., Cottle, S. (Eds.), Transnational protest and the media: Toward global civil society (pp. 213-224). New York, NY: Peter Lang.

Adi, A., \& Moloney, K. (2012). The importance of scale in occupy movement protests: A case study of a local occupy protest as a communication tool through public relations and social media. Revista Internacional De Relaciones Públicas, 4(2), 97-122.

Allagui, I., \& Breslow, H. (2016). Social media for public relations: Lessons from four effective cases. Public Relations Review, 42(1), 20-30. doi:10.1016/j.pubrev.2015.12.001

Anisimova O., Vasylenko V., Fedushko S. (2019). Social networks as a tool for a higher education institution image creation. CEUR Workshop Proceedings, 2392, 54-65. http://ceurws.org/Vol-2392/paper5.pdf

Avidar, R. (2011). Israeli public relations and the internet. Israel Affairs, 17(3), 401-421.

Basil, D. Z., \& Erlandson, J. (2008). Corporate social responsibility website representations: A longitudinal study of internal and external self-presentations. Journal of Marketing Communications, 14(2), 125-137. doi:10.1080/13527260701858497

Callison, C. (2003). Media relations and the internet: How fortune 500 company web sites assist journalists in news gathering. Public Relations Review, 29(1), 29-41. doi:10.1016/S03638111(02)00196-0

Chen, K., \& Chan, A. H. S. (2014). Predictors of geotechnology acceptance by older Hong Kong Chinese. Technovation, 34(2), 126-135. doi:10.1016/j.technovation.2013.09.010

Chen, X., Chen, O, \& Chen, N. (2012). How public relations functions as news sources in China. Public Relations Review, 38(5), 697-703. doi:10.1016/j.pubrev.2012.04.007

Childers, L. (1989). J. Grunig's asymmetrical and symmetrical models of public relations: Contrasting features and ethical dimensions. IEEE Transactions on Professional Communication, 32(2), 89-93.

Constantinides, E., \& Stagno, M. C. Z. (2012). Higher education marketing: A study on the impact of social media on study selection and university choice. International Journal of Technology and Educational Marketing (IJTEM), 2(1), 41-58.

Curtis, L., Edwards, C., Fraser, K. L., Gudelsky, S., Holmquist, J., Thornton, K., \& Sweetser, K. D. (2010). Adoption of social media for public relations by non-profit organizations. Public Relations Review, 36(1), 90-92. doi:http://dx.doi.org/10.1016/j.pubrev.2009.10.003

De Bussy, N. M., \& Wolf, K. (2009). The state of Australian public relations: Professionalization and paradox. Public Relations Review, 35(4), 376-381. doi:10.1016/j.pubrev.2009.07.005

Desai, S., \& Han, M. (2019, April). Social media content analytics beyond the text: A case study of university branding in Instagram. Proceedings of the 2019 ACM Southeast Conference, 94101.

DiStaso, M. W., McCorkindale, T., \& Wright, D. K. (2011). How public relations executives perceive and measure the impact of social media in their organizations. Public Relations Review, 37(3), 325-328. 
Doolan, D. M., \& Froelicher, E. S. (2009). Using an existing data set to answer new research questions: A methodological review. Research and Theory for Nursing Practice, 23(3), 203215.

Dougall, E. K. (2006). Tracking organization public relationships over time: A framework for longitudinal research. Public Relations Review, 32(2), 174-176. doi:10.1016/j.pubrev.2006.02.012

Ridley, D. (2017). How today's colleges and universities are using social media. Retrieved from Vital Design https://vtldesign.com/digital-marketing/social-media/how-todays-colleges-anduniversities-are-using-social-media.

Eger, L., Egerova, D., \& Kryston, M. (2019). Facebook and public relations in higher education. Romanian Journal of Communication and Public Relations, 21(1), 7-30.

Esrock, S. L., \& Leichty, G. B. (1998). Social responsibility and corporate web pages: Selfpresentation or agenda setting? Public Relations Review, 24(3), 305-319.

Esrock, S. L., \& Leichty, G. B. (2000). Organization of corporate web pages: Publics and functions. Public Relations Review, 26(3), 327-344.

Eyrich, N., Padman, M.L., \& Sweetser, K. D. (2008). PR practitioners' use of social media tools and communication technology. Public Relations Review, 34(4), 412-414. doi:10.1016/j.pubrev.2008.09.010.

Frame, A., \& Brachotte, G. (2015). Le tweet stratégique: Use of Twitter as a PR tool by French politicians. Public Relations Review, 41(2), 278-287. doi:10.1016/j.pubrev.2014.11.005.

FUTURARTS (2011). Üniversitelerin sosyal medya kullanımı, Retrieved from: https://futurarts.wordpress.com/ (Access Date: August 24, 2017).

Gümüş, N., Türkel, E. ve Gözde, Ş. E. N. (2015). Üniversite tercihlerinde öğrencilerin yararlandıkları bilgi kaynaklarının belirlenmesine yönelik kastamonu üniversitesi öğrencileri üzerinde bir araştırma. İstanbul Gelişim Üniversitesi Sosyal Bilimler Dergisi, 2(2), 43-67.

Hallahan, K. (2001). Improving public relations web sites through usability research. Public Relations Review, 27(2), 223-239. doi:10.1016/S0363-8111(01)00082-0.

Hox, J.J., \& Boeije, H.R. (2005). Data collection, primary versus secondary. Encyclopedia of Social Measurement, 593-599.

Hou, Z., Zhu, Y., \& Bromley, M. (2013). Understanding public relations in China: Multiple logics and identities. Journal of Business and Technical Communication, 27(3), 308-328. doi:10.1177/1050651913479926.

Internet World Stats. (2015). Retrieved from https://www.internetworldstats.com/. (Access Date: June 13, 2020).

Jun, J. (2011). How climate change organizations utilize websites for public relations. Public Relations Review, 37(3), 245-249. doi:10.1016/j.pubrev.2011.04.001.

Kent, M. L. (2010). Directions in social media for professionals and scholars. In R. L. Heath (Ed.), Handbook of Public Relations ( $2^{\text {nd }} e d$ ), pp. 643-656. Thousand Oaks, CA: Sage

Kilic, A, O., \& Ataberk, U. (2012). Social media adoption among Turkish public relations professionals: A survey of practitioners. Public Relations Review, 38(1), 56-63. doi:10.1016/j.pubrev.2011.11.002.

Kimmons, R., Veletsianos, G., \& Woodward, S. (2017). Institutional uses of Twitter in US higher education. Innovative Higher Education, 42(2), 97-111 
Lahav, T. (2014). Public relations activity in the new media in Israel 2012: Changing relationships. Public Relations Review, 40(1), 25-32. doi:10.1016/j.pubrev.2013.12.007.

Lee, H.-Y., Ahn, H., Kim, H. K., \& Lee, J. (2014). Comparative analysis of trust in online communities. Procedia Computer Science, 31, 1140-1149. doi:10.1016/j.procs.2014.05.370.

Lee, H., Park, Sun- A., Lee, Young Ah., \& Cameron, G.T. (2010). Assessment of motion media on believability and credibility: An exploratory study. Public Relations Review, 36(3), 310-312. doi:10.1016/j.pubrev.2010.04.003.

Lee, W., Xiong, L., \& Hu, C. (2012). The effect of Facebook users' arousal and valence on intention to go to the festival: Applying an extension of the technology acceptance model. International Journal of Hospitality Management, 31(3), 819-827. doi:10.1016/j.ijhm.2011.09.018.

Lovejoy, K., Waters, R. D., \& Saxton, G. D. (2012). Engaging stakeholders through twitter: How non-profit organizations are getting more out of 140 characters or less. Public Relations Review, 38(2), 313-318. doi:http://dx.doi.org/10.1016/j.pubrev.2012.01.005.

Magee, T., Lee, S.M., Giuliano, K.K., \& Munro, B. (2006). Generating new knowledge from existing data: The use of large data sets for nursing research. Nursing Research, 55(2), 50-56.

Maresova, P., Hruska, J., \& Kuca, K. (2020). Social media university branding. Education Sciences, 10(3), 74.

McAllister-Spooner, S. M. (2009). Fulfilling the dialogic promise: a ten-year reflective survey on dialogic internet principles. Public Relations Review, 35(3), 320-322.

Momoc, A. (2013). Social media-PR tools for Romanian politicians? Procedia Social and Behavioral Sciences, 81, 116-121. doi:10.1016/j.sbspro.2013.06.398.

Moore, J.H., \& Carlson, A. (2013). Reaching the audience: New communication technology practices in college sports public relations. Journal of Global Scholars of Marketing Science, 23(1), 109-126. doi:10.1080/21639159.2012.744515.

Myers, C. (2015). An analysis of social media ownership litigation between organizations and PR practitioners. Public Relations Review, 41(4), 515-522. doi:10.1016/j.pubrev.2015.05.003.

Paek, H.-J., Hove, T., Jung, Y., \& Cole, R. T. (2013). Engagement across three social media platforms: An exploratory study of a cause-related PR campaign. Public Relations Review, 39(5), 526-533. doi:10.1016/j.pubrev.2013.09.013.

Rubin, A. (2011). Living in the age of emotional rationality: Wendell bell, social media and the challenges of value change. Futures, 43(6), 583-589. doi:10.1016/j.futures.2011.04.006.

Sanderson, J., Barnes, K., Williamson, C., \& Kian, E. T. (2016). 'How could anyone have predicted that \#askjameis would go horribly wrong?' Public relations, social media, and hashtag hijacking. Public Relations Review, 42(1), 31-37. doi:10.1016/j.pubrev.2015.11.005.

Seçkiner, E. B., \& Tahtalioğlu, H. (2017). Türkiye'de üniversitelerin sosyal medya kullanimi: Gazi Üniversitesi örneği. Süleyman Demirel Üniversitesi İktisadi ve İdari Bilimler Fakülte Dergisi, 22(Kayfor 15 özel sayıs1), 2405-2423.

Shin, J.-H., Carithers, H., Lee, S., Graham, M., \& Hendricks, N. (2013). The current trends in social media usage at corporations: analysis of Facebook fan pages of fortune 500 companies. In Al-Deen, H. S. N. \& Hendricks, J. A. (Eds.), Social media and strategic communications (pp. 62-79). London: Palgrave Macmillan UK.

Stewart, D. W., \& Kamins, M.A. (1993). Secondary research: Information sources and methods, $2^{\text {nd }}$ ed. Newbury Park, CA: Sage. 
Sommerfeldt, E. J., Kent, M. L., \& Taylor, M. (2012). Activist practitioner perspectives of website public relations: Why aren't activist websites fulfilling the dialogic promise? Public Relations Review, 38(2), 303-312. doi:http://dx.doi.org/10.1016/j.pubrev.2012.01.001.

Toledano, M., \& Avidar, R. (2016). Public relations, ethics, and social media: A cross-national study of PR practitioners. Public Relations Review, 42(1), 161-169. doi:10.1016/j.pubrev.2015.11.012.

Toledano, M., \& Wolland, L. (2011). Ethics 2.0: Social media implications for professional communicators. ethical space: The International Journal of Communication Ethics, 8(3-4), 43.

Triantafillidou, A., \& Yannas, P. (2014). How public relations agencies in Greece respond to digital trends. Public Relations Review, 40(5), 815-817. doi:10.1016/j.pubrev.2014.09.004.

Valentini, C. (2015). Is using social media “Good” for the public relations profession? A critical reflection. Public Relations Review, 41(2), 170-177. doi:http://dx.doi.org/10.1016/j.pubrev.2014.11.009.

Valentini, C., \& Kruckeberg, D. (2012). New media versus social media: A conceptualization of their meanings, uses, and implications for public relations. In S. Duhe (Ed.), New Media and Public Relations, (pp.3-12). Newyork: Peter Lang.

Van Der Meer., T. G. L. A., Verhoeven, P., Beentjes, H., \& Vliegenthart, R. (2014). When frames align: the interplay between PR, news media, and the public in times of crisis. Public Relations Review, 40(5), 751-761. doi:10.1016/j.pubrev.2014.07.008.

Van Leuven, S., Deprez, A., \& Raeymaeckers, K. (2013). Towards more balanced news access? a study on the impact of cost-cutting and web 2.0 on the mediated public sphere. Journalism, 15(7), 850-867. doi:10.1177/1464884913501837.

Verhoeven, P., Tench, R., Zerfass, A., Moreno, A., \& Verčič, D. (2012). How European PR practitioners handle digital and social media. Public Relations Review, 38(1), 162-164. doi:10.1016/j.pubrev.2011.08.015.

Waters, R.D., Burnett, E., Lamm, A., \& Lucas, J. (2009). Engaging stakeholders through social networking: how non-profit organizations are using Facebook. Public Relations Review, 35(2), 102-106. doi:10.1016/j.pubrev.2009.01.006.

Webometrics. (2017). Ranking web of universities in Turkey. Retrieved from http://www.webometrics.info/en/Asia/Turkey (Access Date: June 10, 2020).

Webometrics. (2021a, January). Current calculation of indicators. Ranking web of universities. Retrieved from http://www.webometrics.info/en/Methodology. (Access Date: June 10, 2020).

Webometrics. (2021b, January). Methodology. Ranking web of universities. Retrieved from http://www.webometrics.info/en/Methodology. (Access Date: June 10, 2020).

Webometrics. (2021c, January). Philosophy and justification. ranking web of universities. Retrieved from http://www.webometrics.info/en/Methodology. (Access Date: June 10, 2020).

Willis, P. (2015). Preach wine and serve vinegar: public relations, relationships, and doublethink. Public Relations Review, 41(5), 681-688. doi:10.1016/j.pubrev.2014.02.004.

Xifra, J., \& Huertas, A. (2008). Blogging PR: An exploratory analysis of public relations weblogs. Public Relations Review, 34(3), 269-275. doi:10.1016/j.pubrev.2008.03.022.

Ufuk, M. Üniversitelerin yeni yıldızı sosyal medya. Retrieved from http://www.Yeniakit.Com.Tr/Haber/Universitelerin-Yeni-Yildizi-Sosyal-Medya11993.Html (Access date: February 24, 2021). 
Zietsma, C., \& Winn, M. I. (2007). Building chains and directing flows: Strategies and tactics of mutual influence in stakeholder conflicts. Business \& Society. 47(1), 68-101. 